\title{
Intake and digestibility of silages containing pineapple pulp and coast-cross hay with or without urea and markers recovery in sheep
}

\author{
Guilherme Ribeiro Alves ${ }^{1}$, Carlos Augusto de Alencar Fontes ${ }^{2}$, Alberto Magno Fernandes², \\ Elizabeth Fonsêca Processi ${ }^{3}$, Tadeu Silva de Oliveira ${ }^{3}$, Leonardo Siqueira Glória ${ }^{3}$, Raphael dos \\ Santos Gomes ${ }^{3}$
}

\author{
${ }^{1}$ Universidade Federal de Mato Grosso, Departamento de Zootecnia, Rondonópolis, MT, Brazil. \\ ${ }^{2}$ Universidade Estadual do Norte Fluminense Darcy Ribeiro, Laboratório de Zootecnia, Campos dos Goytacazes, RJ, Brazil. \\ ${ }^{3}$ Universidade Estadual do Norte Fluminense Darcy Ribeiro, Programa de Pós-graduação em Ciência Animal, Campos dos Goytacazes, RJ, Brazil.
}

\begin{abstract}
The objective of this study was to evaluate the intake and digestibility of silages containing pineapple pulp and coast-cross hay, with or without addition of urea, and the recovery of the markers chromium oxide $\left(\mathrm{Cr}_{2} \mathrm{O}_{3}\right)$, indigestible neutral detergent fiber (iNDF), indigestible acid detergent fiber (iADF), and indigestible dry matter (iDM), in a digestibility assay, in sheep. Treatments were as follows: two levels of pineapple pulp $\left(818\right.$ and $\left.758 \mathrm{~g} \mathrm{~kg}^{-1}\right)$ and two levels of urea (with and without urea), in a completely randomized design. Twelve sheep (three per treatment) were used, kept in metabolic cages. Fecal excreta were determined by total collection or estimated by using the markers. Marker samples were obtained in morning and afternoon collections, with mean concentrations obtained for both daily activities. The level of silage pulp did not affect intake, while addition of urea increased the intake of crude protein (CP), but did not influence the intakes of dry matter, organic matter, neutral detergent fiber, or acid detergent fiber. The digestibility coefficients of all afore-mentioned fractions increased with the increase in pulp, the same happening with the addition of urea. The internal marker with lowest variability among the internal markers was iADF, with mean values near $100 \%$. Mean recovery of $\mathrm{Cr}_{2} \mathrm{O}_{3}$ was approximately $107 \%$, but with lower variability among treatments. Inclusion of pineapple pulp in silage does not influence intake, while addition of urea only increases the intake of CP. The levels of pineapple pulp in silage with or without urea increase the digestibility of the silage. Indigestible acid detergent fiber is the marker with lowest variability of recovery, with mean recovery for the four silages used very close to $100 \%$.
\end{abstract}

Key Words: by-products, fecal collection, nitrogen compounds

\section{Introduction}

Brazil, China, and India are important pineappleproducing countries, where the crop has favorable soilclimatic conditions for its development (IBGE, 2012). The Brazilian production of pineapple in 2011 was 3,028,781 t, with a total harvested area of 55,765 ha (AGRIANUAL, 2012), generating a considerable production of by-products. Among them is the pulp core, a residue from juice extraction, which, despite having a variable chemical composition due to fruit variety, maturity, quality of photosynthetic production (sugar content), and technology employed in the manufacturing of the preserves, has a high nutritional value, as it is mainly composed of soluble sugars, of which $70 \%$ are sucrose, $20 \%$ are glucose, and $10 \%$ are fructose. It is also constituted of structural carbohydrates, such as

Received June 25, 2015 and accepted February 5, 2016

Corresponding author: alberto@uenf.br

http://dx.doi.org/10.1590/S1806-92902016000400002

Copyright (C) 2016 Sociedade Brasileira de Zootecnia. This is an Open Access article distributed under the terms of the Creative Commons Attribution License (http://creativecommons.org/licenses/by/4.0/), which permits unrestricted use, distribution, and reproduction in any medium, provided the original work is properly cited. hemicellulose, cellulose, hexosans, pentosans, and pectins (Müller, 1978). According to Azevêdo et al. (2011), the chemical composition of the pineapple is: dry matter (DM), $139 \mathrm{~g} \mathrm{~kg}^{-1}$ as fed; crude protein (CP), $71 \mathrm{~g} \mathrm{~kg}^{-1} \mathrm{DM}$; neutral detergent fiber (NDF), $602 \mathrm{~g} \mathrm{~kg}^{-1} \mathrm{DM}$; and total digestible nutrients (TDN), $717.5 \mathrm{~g} \mathrm{~kg}^{-1} \mathrm{DM}$. The DM digestibility is $644.4 \mathrm{~g} \mathrm{~kg}^{-1}$; the NDF digestibility is $630 \mathrm{~g} \mathrm{~kg}^{-1}$; and CP digestibility is $725.9 \mathrm{~g} \mathrm{~kg}^{-1}$.

The higher availability of the pineapple agro-industrial residue coincides with the crop harvest, which takes place in the summer. This is the time of greatest availability of grazing fields of good nutritional value and relatively low cost, which reduces the interest of dairy and meat producers in using this feed resource in its fresh form. Therefore, there is a need for seeking means of preserving the residue for the times of feed scarcity. Of the most common food-preservation techniques applicable to the pineapple residue, dehydration (on the farm, haymaking; in the industry, bran production) or controlled fermentation (through ensilage techniques) are worth mentioning. Despite the low protein as a limitation, the high energy content of residues from the pineapple juice industry is 
evidence of its potential to be used in ruminant feeding (Ferreira et al., 2009).

Thus, the inclusion of non-protein nitrogen sources (NPN) in high-energy silages promotes an increase in the $\mathrm{CP}$ content, improving its nutritional characteristics and the stability of the ensilage matter, thereby reducing DM losses. Among the forms of using NPN, urea is the most widely employed to increase the CP content, improving the animal performance and benefiting the rumen digestibility of the cell wall of plants, because when the peak of protein availability does not happen simultaneously to the volatile fatty acid production peak in the rumen, the production efficiency of the microbial protein decreases. This may cause a reduction of the rumen microorganism population and, as a consequence, the degradation of the fiber is compromised, causing rumen fill (Van Soest, 1994).

Establishing nutritional values to the feed consumed by animals is a challenge to nutritionists. Digestibility is an important parameter for this evaluation (Cochran et al., 1986). To estimate the in vivo digestibility, using the conventional direct method, it is necessary to restrain the animal and have strict feed ingestion and fecal excretion control, which makes its use impracticable in many situations. Thus, the in vivo digestibility has been estimated, more often, using an indirect method employing markers (Fontes et al., 1996). The markers technique consists of using a reference substance or marker that, once supplied in the diet, must be fully recovered in the feces (Iturbide, 1967). Among the markers classified as external used in digestion assays, chromium is the most frequently used for estimating fecal excreta, mainly due to its low cost, being easily incorporated into the feed, being dosed with relative ease and, presumptively, being fully recovered in feces. The most frequent procedure consists of supplying two daily doses with the same mass in defined time intervals, with concomitant fecal collections (Hopper et al., 1978). An adaptation period of five to seven days is necessary before starting the fecal collections, aiming to reach the concentration plateau in the feces (Owens and Hanson, 1992). This procedure is known as continuous infusion. The internal markers present the advantage of being part of the food, and are thus distributed evenly along the gastrointestinal tract during the digestion and excretion processes (Piaggio et al., 1991) These markers are constituted of indigestible fractions of the feed, such as indigestible neutral detergent fiber (iNDF) and indigestible acid detergent (iADF) (Penning and Johnson, 1983; Cochran et al., 1986; Lippke et al., 1986; Krysl et al., 1988; Resende et al., 1996; Zeoula et al., 2002). Indigestible dry matter has also been used (Detmann et al., 2001).
The objective of this study was to evaluate the intake and digestibility of silage containing two levels of pineapple pulp, with or without urea, and the recovery of external marker chromium oxide and iNDF, iADF, and iDM from fecal samples collected at different times.

\section{Material and Methods}

The present study was conducted in Campos dos Goytacazes, RJ, Brazil ( $21^{\circ} 44^{\prime} 47^{\prime \prime}$ latitude, $41^{\circ} 18^{\prime} 24^{\prime \prime}$ longitude, $12 \mathrm{~m}$ altitude), where the annual average maximum and minimum temperatures are 27.1 and $21.4{ }^{\circ} \mathrm{C}$, respectively, and annual precipitation is $1023 \mathrm{~mm}$. According to Köeppen (1948), the climate of the region is classified as tropical monsoon (AM).

Pineapple pulp and coast-cross hay were used in the composition of the silages. The pineapple pulp was still fresh when it was added to the mixture, as it is produced in the industry. The hay, acquired from a farm in the region, was introduced in the ensilage chopped, aiming to increase the DM content of the ensilaged residue and to evaluate the effect of its inclusion on the qualitative characteristics of the silage. Two mixtures containing pineapple pulp and coast-cross hay were prepared. The non-protein mixture (urea) was prepared with $700 \mathrm{~g} \mathrm{~kg}^{-1}$ of urea and $300 \mathrm{~g} \mathrm{~kg}^{-1}$ of ammonium sulfate and was introduced to elevate the nitrogen content of the ensiled material and observe possible effects of ammonia, if released, on the neutral detergent fiber digestibility. The four treatments were defined as follows: $818 \mathrm{~g} \mathrm{~kg}^{-1}$ pulp $+182 \mathrm{~g} \mathrm{~kg}^{-1}$ hay (259.2 $\left.\mathrm{g} \mathrm{kg}^{-1} \mathrm{DM}\right) ; 809.3 \mathrm{~g} \mathrm{~kg}^{-1}$ pulp $+180 \mathrm{~g} \mathrm{~kg}^{-1}$ hay $+107 \mathrm{~g}$ $\mathrm{kg}^{-1}$ urea $\left(267.1 \mathrm{~g} \mathrm{~kg}^{-1} \mathrm{DM}\right) ; 758 \mathrm{~g} \mathrm{~kg}^{-1}$ pulp $+242 \mathrm{~g} \mathrm{~kg}^{-1}$ hay (301.8 $\mathrm{g} \mathrm{kg}^{-1} \mathrm{DM}$ ); and $748 \mathrm{~g} \mathrm{~kg}^{-1}$ pulp $+239.5 \mathrm{~g} \mathrm{~kg}^{-1}$ hay + $125 \mathrm{~g} \mathrm{~kg}^{-1}$ urea ( $\left.311 \mathrm{~g} \mathrm{~kg}^{-1} \mathrm{DM}\right)$, distributed in a completely randomized design with a $2 \times 2$ factorial arrangement consisting of two levels of pineapple pulp and two levels of urea (with and without), with three replicates per treatment, as described in the mathematical model below:

$$
\mathrm{y}_{i j}=\mu+\alpha_{i}+\beta_{j}+\alpha \beta_{i j}+e_{i j}
$$

in which $\mathrm{y}_{i j}$ corresponds to the observation performed in treatment $i$, associated with the $j$-th level of urea; $\mu$ represents the overall mean; $\alpha_{i}$ corresponds to the effect of treatment $i(i=1,2) ; \beta_{j}$ represents the effect of the $j$-th level of urea; $\alpha \beta_{i j}$ is the interaction between treatment $i$ and the $j$-th level of urea; and $e_{i j}$ corresponds to the random error, assumed as normal, independent and identically distributed with zero mean and variance $\sigma^{2}$.

The mixtures in the indicated proportions were placed in 12 plastic barrels with 200-L capacity, with three replicates for each mixture, and remained ensiled for approximately 180 days. 
Twelve castrated male sheep with body weight of $\pm 30 \mathrm{~kg}$ were used for determining the apparent digestibility coefficients of DM, CP, and NDF true coefficient. The animals were treated in individual metabolic cages and randomly distributed into the treatments. Total feces collection was performed during seven days using collection bags. Animals were dewormed two weeks before the onset of the experiment. The assay lasted 21 days, 14 of them for adaptation and seven for sample collection.

The feed was supplied once daily, at $08.00 \mathrm{~h}$, keeping the orts at around 5 to $10 \%$ of the offered amount, during the adaptation period, to ensure voluntary intake. On the collection days, the feed was supplied in a pre-determined amount, equivalent to the average intake assessed in the five last days of the adaptation period. The amounts of feed offered daily, as well as individual orts, were recorded. Feed and orts samples were collected daily to determine the intake and were stored in a freezer for later processing. After thawing, the composite samples were made and then dried in a forced-ventilation oven at $55{ }^{\circ} \mathrm{C}$ for $72 \mathrm{~h}$. Subsequently, they were processed in a knife mill using a 1-mm sieve, and then stored in glass bottles at room temperature for laboratory analyses. The dry matter (DM), crude fat, lignin, crude protein (CP), and acid detergent fiber (ADF) contents were determined according to AOAC (1990); and amylase-treated, ash-free neutral detergent fiber (aNDFom), according to Van Soest et al. (1991).

The recovery of external marker chromium oxide and internal markers (i.e., indigestible fractions iNDF, iADF, and iDM) was also analyzed. Fecal excretion was determined by total collection using collection bags, estimated using the external marker chromium oxide and the internal markers iDM, iNDF, and iADF. The animals received, during 14 days, twice daily, at $08.00 \mathrm{~h}$ and $16.00 \mathrm{~h}$, two grams of $\mathrm{Cr}_{2} \mathrm{O}_{3}$, stored in paper cartridge and placed directly in the esophagus with an esophageal tube. After the 14-day standardization period, the fecal sample collection was started, lasting seven consecutive days. Fecal samples were obtained (from the rectum) at the time the $\mathrm{Cr}_{2} \mathrm{O}_{3}$ was supplied, by opening the collector bags. Total daily fecal excretion was determined by emptying the collector bags and weighing the feces found in them, adding the weight of the rectum samples. Representative samples of the total feces were collected daily. Individual composite samples from feces obtained by total collection were constituted after pre-drying the daily samples, including the amounts of daily feces proportional to the total excreted in each day in the composite sample.

Separated individual composite samples were also constituted for the feces collected in the morning and afternoon, and combined samples from morning and afternoon defecation. In the constitution of composite samples of the feces obtained by rectum collection, a constant amount of pre-dried feces collected each day was used. The feed and feces samples were pre-dried in a forced-ventilation oven at $55{ }^{\circ} \mathrm{C}$ for $72 \mathrm{~h}$ to determine the chemical composition, as mentioned above. Chromium was determined according to Kimura and Miller (1957). To quantify the internal markers iDM, iNDF, and iADF present in feed, orts, and feces, the pre-dried samples were milled using a 1-mm mesh sieve and incubated in vitro for $144 \mathrm{~h}$. Indigestible dry matter was directly determined after drying the incubation residue in an oven at $105^{\circ} \mathrm{C}$ for $12 \mathrm{~h}$. Internal markers iNDF and iADF were determined by extraction in neutral and acid detergents, respectively, and later oven-drying.

The estimated fecal excreta values using the internal markers iDM, iNDF, and iADF and the external marker chromium oxide $\left(\mathrm{Cr}_{2} \mathrm{O}_{3}\right)$ were obtained by the following equation:

$$
\mathrm{FE}\left(\mathrm{kg} \mathrm{day}^{-1}\right)=\mathrm{D}\left(\mathrm{g} \mathrm{day}^{-1}\right) / \mathrm{C}\left(\mathrm{g} \mathrm{kg}^{-1}\right),
$$

in which $\mathrm{FE}$ = fecal excretion; $\mathrm{D}=$ daily intake of marker; and $\mathrm{C}=$ fecal concentration of the marker.

The recovery of the markers was determined indirectly, based on fecal recovery. Three different fecal recovery times were estimated for each marker: collection in the morning; collection in the afternoon; and using the morning and afternoon means, respectively, with the purpose of comparing the results obtained with one and two daily collections and checking possible influences of the collection methods (total collection and use of markers), as described in the mathematical model below:

$$
y_{i j k}=\mu+\alpha_{i}+\tau_{j}+\beta_{k}+\alpha \beta_{i k}+e_{i j k},
$$

in which $y_{i j k}$ corresponds to the observation performed on treatment $i$, associated with the $\mathrm{j}$-th level of urea; $\mu$ represents the overall mean; $\alpha_{i}$ corresponds to the effect of treatment $i(i=1,2) ; \tau_{j}$ represents the effect of collection time $j ; \beta_{k}$ represents the effect of collection method $k ; \alpha \beta_{i k}$ is the interaction between treatment $i$ and collection method $k$; and $e_{i j k}$ corresponds to the random error, assumed as normal, independent and identically distributed with zero mean and variance $\sigma^{2}$.

The formulae used in the calculation of the fecal and markers recovery are presented below:

$\mathrm{FR}=($ Estimated amount of fecal DM/Observed amount of

$$
\begin{gathered}
\text { fecal DM) } \times 100 \\
M R=1 / F R,
\end{gathered}
$$

in which $\mathrm{FR}=$ fecal recovery and $\mathrm{MR}=$ marker recovery.

After analysis of variance, the sum of squares for treatments for the variables $\mathrm{DM}, \mathrm{OM}, \mathrm{CP}, \mathrm{NDF}$, and $\mathrm{ADF}$ 
intakes (in kg per day and per metabolic body size $\left(\mathrm{mbs}^{-1}\right)$ ) and digestibility coefficients was decomposed into three orthogonal contrasts, aiming to compare between the levels of pulp and, within these, between the levels of urea, using the Duncan test at $\alpha=0.05$ probability.

In the analysis of variance of data regarding fecal excretion, the model used included the effects of treatment and time of collection. Mean values for fecal excretion of the four treatments with each marker and the different collection times were compared using the Duncan test at $\alpha=0.05$ probability. The effects of collection methods (total collection and use of markers) were also analyzed. These were then compared using the Duncan test at $\alpha=0.05$ probability.

\section{Results}

There was no interaction effect $(\mathrm{P}>0.05)$ between pineapple pulp and urea for the intake and digestibility variables. Pineapple pulp levels in the silages did not influence $(\mathrm{P}>0.05)$ the intakes of $\mathrm{DM}, \mathrm{OM}, \mathrm{CP}, \mathrm{NDF}$, and $\mathrm{ADF}$ of the sheep, expressed in $\mathrm{kg} \mathrm{day}^{-1}$ or in $\mathrm{g} \mathrm{mbs}^{-1}$, although an upward trend in the intake values was observed for silages containing the lower level of pulp (Tables 1 and 2).

There were differences $(\mathrm{P}<0.05)$ between the levels of pineapple pulp in silages regarding the digestibility coefficients of DM, OM, CP, and NDF; silages with the higher pulp concentration presented greater digestibility. However, no difference was detected $(\mathrm{P}>0.05)$ between the pulp levels regarding ADF digestibility (Tables 3 and 4). In silages containing $818 \mathrm{~g} \mathrm{~kg}^{-1}$ pineapple pulp, addition

Table 1 - P-values of the orthogonal contrasts regarding pineapple pulp levels $(\mathrm{P} 818 \times \mathrm{P} 758)$ and presence of urea within pineapple pulp levels for the intake of chemical components

\begin{tabular}{lcccc}
\hline & & \multicolumn{2}{c}{ Pineapple pulp level } \\
\cline { 3 - 3 } Variable & $\mathrm{P} 818 \times \mathrm{P} 758$ & P818 & & P758 \\
\cline { 3 - 3 } & & $\begin{array}{c}\text { Without urea } \times \text { With } \\
\text { urea }\end{array}$ & $\begin{array}{c}\text { Without urea } \times \text { With } \\
\text { urea }\end{array}$ \\
\hline $\mathrm{DM}^{1}$ & 0.3645 & 0.6538 & & 0.3679 \\
$\mathrm{OM}^{1}$ & 0.3623 & 0.6672 & & 0.3853 \\
$\mathrm{CP}^{1}$ & 0.3874 & 0.0304 & & 0.0103 \\
$\mathrm{NDF}^{1}$ & 0.5112 & 0.4982 & & 0.1365 \\
$\mathrm{ADF}^{1}$ & 0.3360 & 0.4639 & & 0.3424 \\
& & & \\
$\mathrm{DM}^{2}$ & 0.2505 & 0.5332 & 0.2354 \\
$\mathrm{OM}^{2}$ & 0.2474 & 0.5511 & 0.2512 \\
$\mathrm{CP}^{2}$ & 0.2198 & 0.0041 & 0.0010 \\
$\mathrm{NDF}^{2}$ & 0.4099 & 0.3621 & 0.0590 \\
$\mathrm{ADF}^{2}$ & 0.2257 & 0.3233 & 0.2158 \\
\hline
\end{tabular}

P818 - $818 \mathrm{~g} \mathrm{~kg}^{-1}$ pineapple pulp $+182 \mathrm{~g} \mathrm{~kg}^{-1}$ hay; P758 - $758 \mathrm{~g} \mathrm{~kg}^{-1}$ pineapple pulp $+242 \mathrm{~g} \mathrm{~kg}^{-1}$ hay.

$\mathrm{DM}$ - dry matter; OM - organic matter; CP - crude protein; NDF - neutral detergent fiber; ADF - acid detergent fiber.

${ }_{1}^{1}$ Absolute intake rate of the nutrient, $\mathrm{kg} \mathrm{day}^{-1}$.

${ }^{2}$ Relative intake rate in relation to metabolic body size, $\mathrm{kg}$ day ${ }^{-1} \mathrm{~kg}^{-0.75}$. of urea increased $(\mathrm{P}<0.05)$ the digestibility coefficients of $\mathrm{DM}, \mathrm{OM}, \mathrm{CP}$, and NDF, but did not influence $(\mathrm{P}>0.05)$ the digestibility of ADF (Tables 3 and 4). In those containing $758 \mathrm{~g} \mathrm{~kg}^{-1}$ pineapple pulp, addition of urea increased

Table 2 - Means and coefficient of variation (CV) for the intake of chemical components

\begin{tabular}{|c|c|c|c|c|c|c|c|}
\hline \multirow[b]{3}{*}{ Variable } & \multirow[b]{3}{*}{ P818 } & \multirow[b]{3}{*}{ P758 } & \multicolumn{4}{|c|}{ Pineapple pulp level } & \multirow[b]{3}{*}{$\mathrm{CV}, \%$} \\
\hline & & & \multicolumn{2}{|c|}{ P818 } & \multicolumn{2}{|c|}{ P758 } & \\
\hline & & & $\begin{array}{c}\text { Without } \\
\text { urea }\end{array}$ & $\begin{array}{l}\text { With } \\
\text { urea }\end{array}$ & $\begin{array}{c}\text { Without } \\
\text { urea }\end{array}$ & $\begin{array}{l}\text { With } \\
\text { urea }\end{array}$ & \\
\hline $\mathrm{DM}^{1}$ & 0.55 & 0.64 & 0.58 & 0.52 & 0.71 & 0.58 & 27.04 \\
\hline $\mathrm{OM}^{1}$ & 0.50 & 0.58 & 0.53 & 0.47 & 0.64 & 0.53 & 27.16 \\
\hline $\mathrm{CP}^{1}$ & 0.078 & 0.093 & 0.05 & 0.11 & 0.05 & 0.13 & 33.17 \\
\hline $\mathrm{NDF}^{1}$ & 0.35 & 0.39 & 0.38 & 0.32 & 0.46 & 0.32 & 27.11 \\
\hline $\mathrm{ADF}^{1}$ & 0.31 & 0.36 & 0.34 & 0.28 & 0.40 & 0.32 & 26.48 \\
\hline $\mathrm{DM}^{2}$ & 42.24 & 48.82 & 44.69 & 39.80 & 53.64 & 44.00 & 20.21 \\
\hline $\mathrm{OM}^{2}$ & 38.03 & 44.02 & 40.15 & 35.92 & 48.22 & 39.83 & 20.27 \\
\hline $\mathrm{CP}^{2}$ & 5.94 & 7.04 & 3.63 & 8.25 & 4.12 & 9.97 & 21.97 \\
\hline $\mathrm{NDF}^{2}$ & 26.81 & 29.70 & 29.08 & 24.53 & 34.88 & 24.52 & 20.41 \\
\hline $\mathrm{ADF}^{2}$ & 23.50 & 27.34 & 25.68 & 21.33 & 30.12 & 24.56 & 19.92 \\
\hline
\end{tabular}

P818 - $818 \mathrm{~g} \mathrm{~kg}^{-1}$ pineapple pulp $+182 \mathrm{~g} \mathrm{~kg}^{-1}$ hay; P758 - $758 \mathrm{~g} \mathrm{~kg}^{-1}$ pineapple pulp $+242 \mathrm{~g} \mathrm{~kg}^{-1}$ hay.

DM - dry matter; OM - organic matter; CP - crude protein; NDF - neutral detergent fiber; ADF - acid detergent fiber.

${ }^{1}$ Absolute intake rate of the nutrient, $\mathrm{kg}_{\text {day }}{ }^{-1}$.

${ }^{2}$ Relative intake rate in relation to metabolic body size, $\mathrm{kg}$ day ${ }^{-1} \mathrm{~kg}^{-0.75}$

Table 3 - P-values of the orthogonal contrasts regarding pineapple pulp levels $(\mathrm{P} 818 \times \mathrm{P} 758)$ and presence of urea within pineapple pulp levels for the digestibility of chemical components $\left(\mathrm{g} \mathrm{kg}^{-1} \mathrm{DM}\right)$

\begin{tabular}{lcccc}
\hline & & \multicolumn{2}{c}{ Pineapple pulp level } \\
\cline { 3 - 3 } Variable & P818 $\times$ P758 & P818 & & P758 \\
\cline { 3 - 3 } & & $\begin{array}{c}\text { Without urea } \times \text { With } \\
\text { urea }\end{array}$ & & $\begin{array}{c}\text { Without urea } \times \text { With } \\
\text { urea }\end{array}$ \\
\hline DM & 0.0502 & 0.0222 & & 0.0592 \\
OM & 0.0162 & 0.0032 & & 0.0347 \\
CP & 0.0022 & $<0.0001$ & & $<0.0001$ \\
NDF & 0.0302 & 0.0417 & & 0.8689 \\
ADF & 0.1652 & 0.3263 & & 0.1771 \\
\hline
\end{tabular}

P818 - $818 \mathrm{~g} \mathrm{~kg}^{-1}$ pineapple pulp $+182 \mathrm{~g} \mathrm{~kg}^{-1}$ hay; $\mathrm{P} 758-758 \mathrm{~g} \mathrm{~kg}^{-1}$ pineapple pulp $+242 \mathrm{~g} \mathrm{~kg}^{-1}$ hay.

DM - dry matter; OM - organic matter; $\mathrm{CP}$ - crude protein; NDF - neutral detergent fiber; ADF - acid detergent fiber.

Table 4 - Means and coefficients of variation for the digestibility of chemical components $\left(\mathrm{g} \mathrm{kg}^{-1} \mathrm{DM}\right)$

\begin{tabular}{|c|c|c|c|c|c|c|c|}
\hline \multirow[b]{3}{*}{ Variable } & \multirow[b]{3}{*}{ P818 } & \multirow[b]{3}{*}{ P758 } & \multicolumn{4}{|c|}{ Pineapple pulp level } & \multirow[b]{3}{*}{$\mathrm{CV}, \%$} \\
\hline & & & \multicolumn{2}{|c|}{ P818 } & \multicolumn{2}{|c|}{ P758 } & \\
\hline & & & $\begin{array}{c}\text { Without } \\
\text { urea }\end{array}$ & $\begin{array}{l}\text { With } \\
\text { urea }\end{array}$ & $\begin{array}{c}\text { Without } \\
\text { urea }\end{array}$ & $\begin{array}{l}\text { With } \\
\text { urea }\end{array}$ & \\
\hline DM & 58.32 & 53.06 & 53.76 & 62.88 & 49.52 & 56.61 & 7.09 \\
\hline $\mathrm{OM}$ & 63.38 & 57.37 & 57.58 & 69.17 & 53.82 & 60.92 & 5.67 \\
\hline $\mathrm{CP}$ & 66.04 & 54.69 & 50.09 & 81.99 & 28.89 & 80.48 & 5.57 \\
\hline $\mathrm{NDF}$ & 68.83 & 63.24 & 65.19 & 72.47 & 62.99 & 63.50 & 7.78 \\
\hline $\mathrm{ADF}$ & 59.60 & 55.65 & 57.69 & 61.51 & 52.94 & 58.36 & 7.33 \\
\hline
\end{tabular}

P818 - $818 \mathrm{~g} \mathrm{~kg}^{-1}$ pineapple pulp $+182 \mathrm{~g} \mathrm{~kg}^{-1}$ hay; P758 $-758 \mathrm{~g} \mathrm{~kg}^{-1}$ pineapple pulp $+242 \mathrm{~g} \mathrm{~kg}^{-1}$ hay.

$\mathrm{DM}$ - dry matter; OM - organic matter; $\mathrm{CP}$ - crude protein; NDF - neutral detergent fiber; ADF - acid detergent fiber. 
$(\mathrm{P}>0.05)$ the digestibility of DM, OM, and $\mathrm{CP}$, but did not affect the digestibility of NDF and ADF.

There was no interaction effect $(\mathrm{P}>0.05)$ between treatments and collection times for fecal excretion. The mean fecal excretions obtained by the four markers in the three collection times were very similar, not differing $(\mathrm{P}>0.05)$ from each other (Table 5). The variability of each

Table 5 - Fecal production measured by total collection, estimated by different markers according to treatment

\begin{tabular}{|c|c|c|c|c|c|}
\hline \multirow[b]{2}{*}{$\begin{array}{l}\text { Marker and } \\
\text { collection time }\end{array}$} & \multicolumn{4}{|c|}{ Treatment } & \multirow[b]{2}{*}{ Mean } \\
\hline & $\begin{array}{l}818 \mathrm{~g} \text { of } \\
\text { pulp }\end{array}$ & $\begin{array}{c}818 \mathrm{~g} \text { of } \\
\text { pulp+urea }\end{array}$ & $\begin{array}{c}758 \mathrm{~g} \text { of } \\
\text { pulp }\end{array}$ & $\begin{array}{c}758 \text { of } \\
\text { pulp+urea }\end{array}$ & \\
\hline & \multicolumn{4}{|c|}{ Fecal excretion $\left(\mathrm{kg}\right.$ day $\left.^{-1}\right)$} & \\
\hline Total collection & 0.3590 & 0.2524 & 0.2715 & 0.1922 & 0.2688 \\
\hline $\begin{array}{l}\mathrm{Cr}_{2} \mathrm{O}_{3} \\
\text { Morning } \\
\text { Afternoon } \\
\text { Mean }\end{array}$ & $\begin{array}{l}0.3505 \\
0.3265 \\
0.3385\end{array}$ & $\begin{array}{l}0.2167 \\
0.2235 \\
0.2201\end{array}$ & $\begin{array}{l}0.2793 \\
0.2778 \\
0.2785\end{array}$ & $\begin{array}{l}0.1718 \\
0.1748 \\
0.1733\end{array}$ & $\begin{array}{l}0.2546 \\
0.2506 \\
0.2526\end{array}$ \\
\hline $\begin{array}{l}\text { iNDF } \\
\text { Morning } \\
\text { Afternoon } \\
\text { Mean }\end{array}$ & $\begin{array}{l}0.3113 \\
0.3116 \\
0.3065\end{array}$ & $\begin{array}{l}0.2281 \\
0.2233 \\
0.2257\end{array}$ & $\begin{array}{l}0.2541 \\
0.2589 \\
0.2565\end{array}$ & $\begin{array}{l}0.2627 \\
0.2576 \\
0.2602\end{array}$ & $\begin{array}{l}0.2641 \\
0.2604 \\
0.2622\end{array}$ \\
\hline $\begin{array}{l}\text { iADF } \\
\text { Morning } \\
\text { Afternoon } \\
\text { Mean }\end{array}$ & $\begin{array}{l}0.3087 \\
0.3171 \\
0.3129\end{array}$ & $\begin{array}{l}0.2889 \\
0.2609 \\
0.2749\end{array}$ & $\begin{array}{l}0.2466 \\
0.2422 \\
0.2444\end{array}$ & $\begin{array}{l}0.2027 \\
0.2162 \\
0.2094\end{array}$ & $\begin{array}{l}0.2617 \\
0.2591 \\
0.2604\end{array}$ \\
\hline $\begin{array}{l}\text { iDM } \\
\text { Morning } \\
\text { Afternoon } \\
\text { Mean }\end{array}$ & $\begin{array}{l}0.2870 \\
0.2994 \\
0.2932\end{array}$ & $\begin{array}{l}0.2049 \\
0.2248 \\
0.2148\end{array}$ & $\begin{array}{l}0.2449 \\
0.2399 \\
0.2424\end{array}$ & $\begin{array}{l}0.2498 \\
0.2530 \\
0.2514\end{array}$ & $\begin{array}{l}0.2467 \\
0.2543 \\
0.2505\end{array}$ \\
\hline
\end{tabular}

$\mathrm{Cr}_{2} \mathrm{O}_{3}$ - chromium oxide; iNDF - indigestible neutral detergent fiber; iADF indigestible acid detergent fiber; iDM - indigestible dry matter.

Table 6 - Recovery rates of markers according to treatment

\begin{tabular}{|c|c|c|c|c|c|}
\hline \multirow[b]{2}{*}{$\begin{array}{l}\text { Marker and } \\
\text { collection time }\end{array}$} & \multicolumn{4}{|c|}{ Treatment } & \multirow[b]{2}{*}{ Mean } \\
\hline & $\begin{array}{l}818 \mathrm{~g} \text { of } \\
\text { pulp }\end{array}$ & $\begin{array}{c}818 \mathrm{~g} \text { of } \\
\text { pulp+urea }\end{array}$ & $\begin{array}{c}758 \mathrm{~g} \text { of } \\
\text { pulp }\end{array}$ & $\begin{array}{c}758 \text { of } \\
\text { pulp+urea }\end{array}$ & \\
\hline & \multicolumn{4}{|c|}{ Fecal excretion $\left(\mathrm{kg} \mathrm{day}^{-1}\right)$} & \\
\hline $\mathrm{Cr}_{2} \mathrm{O}_{3}$ & & & & & \\
\hline $\begin{array}{l}\text { Morning } \\
\text { Afternoon }\end{array}$ & $\begin{array}{l}1.0407 \\
1.1154\end{array}$ & $\begin{array}{l}1.1531 \\
1.1183\end{array}$ & $\begin{array}{l}0.9857 \\
0.9922\end{array}$ & $\begin{array}{l}1.0954 \\
1.0725\end{array}$ & $\begin{array}{l}1.0687 \\
1.0746\end{array}$ \\
\hline Mean & 1.0767 & 1.1354 & 0.9887 & 1.0835 & 1.0711 \\
\hline \multicolumn{6}{|l|}{ iNDF } \\
\hline Morning & 1.1499 & 1.1135 & 1.0752 & 0.7326 & 1.0178 \\
\hline Afternoon & 1.1944 & 1.1277 & 1.0483 & 0.7463 & 1.0292 \\
\hline Mean & 1.1715 & 1.1199 & 1.0606 & 0.7394 & 1.0228 \\
\hline \multicolumn{6}{|l|}{ iADF } \\
\hline Morning & 1.1546 & 0.9069 & 1.1049 & 0.9643 & 1.0327 \\
\hline Afternoon & 0.9639 & 1.1230 & 1.1270 & 0.8838 & 1.0244 \\
\hline Mean & 1.1372 & 0.9304 & 1.1158 & 0.9155 & 1.0247 \\
\hline \multicolumn{6}{|l|}{ iDM } \\
\hline Morning & 1.2467 & 1.2374 & 1.1089 & 0.7847 & 1.0944 \\
\hline Afternoon & 1.1897 & 1.1288 & 1.1331 & 0.7676 & 1.0548 \\
\hline Mean & 1.2136 & 1.1754 & 1.1206 & 0.7757 & 1.0713 \\
\hline
\end{tabular}

$\mathrm{Cr}_{2} \mathrm{O}_{3}$ - chromium oxide; iNDF - indigestible neutral detergent fiber; iADF indigestible acid detergent fiber; iDM - indigestible dry matter. marker did not have a direct influence $(\mathrm{P}>0.05)$ on their fecal recovery due to treatments (Table 6). There was no significant effect $(\mathrm{P}>0.05)$ on the digestibility of dry matter between the total collection and use of marker methods (Table 7).

\section{Discussion}

When comparing silages without and with urea on intake, the effect of urea can be observed only for crude protein intake, with greater total intakes and metabolic size unit found in animals receiving the silage without urea, containing both pulp levels ( 818 and $758 \mathrm{~g} \mathrm{~kg}^{-1}$ ). However, there was a downward trend for NDF intake in $\mathrm{g} \mathrm{mbs}^{-1}$ for the silage containing $758 \mathrm{~g} \mathrm{~kg}^{-1}$ pulp without urea in relation to the silage with urea and the same level of pulp. The lack of differences in intake for the majority of the variables studied among the animals fed silage with or without urea is most likely because the $\mathrm{CP}$ content, even from silages without urea, is above the range of 60 to $80 \mathrm{~g} \mathrm{~kg}^{-1}$, below which, according to Minson (1990), Van Soest (1994), and Mertens (1994), rumen fermentation and, consequently, intake, could be limited. According to Schaadt et al. (1966), urea addition might interfere negatively with the palatability of the feed, which may have occurred with the addition of urea at the tested levels. The mean values for DM intake observed for silages containing 818 and $758 \mathrm{~g} \mathrm{~kg}^{-1}$ pineapple pulp, of

Table 7 - Coefficients of digestibility of the silage dry matter of the four treatments measured by total collection of feces, and estimated by different markers

\begin{tabular}{|c|c|c|c|c|c|}
\hline \multirow[b]{2}{*}{$\begin{array}{l}\text { Marker and } \\
\text { collection time }\end{array}$} & \multicolumn{4}{|c|}{ Treatment } & \multirow[b]{2}{*}{ Mean } \\
\hline & $\begin{array}{l}818 \mathrm{~g} \text { of } \\
\text { pulp }\end{array}$ & $\begin{array}{c}818 \mathrm{~g} \text { of } \\
\text { pulp+urea }\end{array}$ & $\begin{array}{c}758 \mathrm{~g} \text { of } \\
\text { pulp }\end{array}$ & $\begin{array}{c}758 \text { of } \\
\text { pulp+urea }\end{array}$ & \\
\hline & \multicolumn{4}{|c|}{ Fecal excretion $\left(\mathrm{kg} \mathrm{day}^{-1}\right)$} & \\
\hline Total collection & 49.20 & 56.48 & 53.50 & 62.70 & 55.47 \\
\hline \multicolumn{6}{|l|}{$\mathrm{Cr}_{2} \mathrm{O}_{3}$} \\
\hline Morning & 50.82 & 62.04 & 52.01 & 65.39 & 57.57 \\
\hline Afternoon & 54.20 & 60.91 & 52.28 & 64.34 & 57.93 \\
\hline Mean & 52.51 & 61.48 & 52.14 & 64.87 & 57.75 \\
\hline \multicolumn{6}{|l|}{ iNDF } \\
\hline Morning & 55.81 & 60.91 & 56.52 & 49.06 & 55.58 \\
\hline Afternoon & 57.42 & 61.44 & 55.70 & 49.91 & 56.12 \\
\hline Mean & 56.61 & 61.17 & 56.11 & 49.48 & 55.85 \\
\hline \multicolumn{6}{|l|}{ iADF } \\
\hline Morning & 55.87 & 51.32 & 57.83 & 61.21 & 56.56 \\
\hline Afternoon & 54.05 & 54.77 & 58.60 & 57.43 & 56.21 \\
\hline Mean & 54.96 & 53.04 & 58.21 & 59.32 & 56.39 \\
\hline \multicolumn{6}{|l|}{ iDM } \\
\hline Morning & 59.26 & 64.78 & 58.08 & 52.27 & 58.60 \\
\hline Afternoon & 56.55 & 60.45 & 58.96 & 51.44 & 56.85 \\
\hline Mean & 57.91 & 62.62 & 58.52 & 51.85 & 57.73 \\
\hline
\end{tabular}

$\mathrm{Cr}_{2} \mathrm{O}_{3}$ - chromium oxide; iNDF - indigestible neutral detergent fiber; iADF indigestible acid detergent fiber; iDM - indigestible dry matter. 
42.24 and $48.82 \mathrm{~g} \mathrm{mbs}^{-1}$, respectively, are above the 29.89, 33.80 , and $29.31 \mathrm{~g} \mathrm{mbs}^{-1}$ obtained by Okamoto et al. (1988) in sheep fed silage from the respective mixtures: sweetcorn husk $+200 \mathrm{~g} \mathrm{~kg}^{-1}$ pineapple pulp, grain-free sweetcorn cob $+200 \mathrm{~g} \mathrm{~kg}^{-1}$ pineapple pulp, and soybean husk $+800 \mathrm{~g} \mathrm{~kg}^{-1}$ pineapple pulp.

However, the greatest influence of urea addition was on the digestibility of DM, OM and, especially, of CP from silages containing both levels of pulp, with a lower effect on the digestibility of NDF and ADF. The digestibility is a characteristic of the feed and indicates the percentage of each nutrient of a feed the animal might use. However, the inclusion of an additive in certain feed can change its digestion, as a result of the associative effect among the feeds (Hennessy et al., 1995). According to Van Soest (1994), when the protein availability peak does not happen simultaneously to the peak of production of volatile fatty acids in the rumen, the efficiency of the production of microbial protein decreases, and, consequently, the fiber degradation is hindered, causing rumen fill, which explains the lower digestibility of the fiber. Considering the influences of the association between the levels of pulp and urea in silages on intake and digestibility, it can be observed that the inclusion of the higher level of pulp and urea in silages did not stimulate feed intake $(\mathrm{P}>0.05)$; on the contrary, a slight decreasing trend could be observed in intake. The digestibility of all fractions, on the other hand, was benefited by the inclusion of a higher level of pulp and by the inclusion of urea. Thus, the decision on the level of pulp to be included depends on the availability and cost of ingredients.

Fecal excretions found for each marker, for each treatment and collection time, were uniform. This indicates that the estimates of fecal excretions based on a single daily collection of feces, either in the morning or in the afternoon, would result in a value close to that obtained when using the mean concentration of both samplings. Especially iNDF and $\mathrm{AADF}$ originated mean values very similar to those observed in the total collection. This would indicate that all four markers could be recommended in research. However, when estimated fecal productions are examined, using each marker, for the different treatments and collection times, it could be noticed that the estimated values, using iNDF and iDM, regarding the silages containing $818 \mathrm{~g} \mathrm{~kg}^{-1}$ of pulp and $758 \mathrm{~g} \mathrm{~kg}^{-1}$ pulp + urea, were considerably distant from the value obtained in total collection. For Fahey and Jung (1983), the greatest limitation of internal markers is their variable recovery in the segments of the digestive tract studied, or even in the feces.

The mean recovery values of the different markers related to collection times were similar. All were near
$100 \%$, especially iNDF and iADF, which differed from $100 \%$ by no more than $3 \%$, regardless of the moment the feces were sampled. These results corroborate Sampaio et al. (2011), who stated that, for all markers, fecal recovery was $100 \%$, indicating that all of them accurately estimate fecal excretion when only recovery aspects are considered. However, when considering the recovery values for each marker, per treatment, it can be seen that iNDF and iDM present greater variability, moving even further away from the $100 \%$ recovery than the $\mathrm{iADF}$ and $\mathrm{Cr}_{2} \mathrm{O}_{3}$, mainly for the treatments containing $818 \mathrm{~g} \mathrm{~kg}^{-1}$ pulp $+182 \mathrm{~g} \mathrm{~kg}^{-1}$ hay and $748 \mathrm{~g} \mathrm{~kg}^{-1}$ pulp $+239.5 \mathrm{~g} \mathrm{~kg}^{-1}$ hay $+125 \mathrm{~g} \mathrm{~kg}^{-1}$ urea. Despite presenting mean recovery of approximately $107 \%, \mathrm{Cr}_{2} \mathrm{O}_{3}$ provided, in general, individual estimates of fecal excretion for treatments closer to the values obtained by total collection. Therefore, it could be assumed that chromium oxide seems to not be affected by different feeding conditions. Sampaio et al. (2011) reported total fecal recovery and no diet effects on the recovery of external markers. Among the internal markers, iADF provided closest fecal excretion estimates, per treatment, to the real excretion. It also presented mean fecal recovery very near $100 \%$. The results of this paper corroborate the work by Berchielli et al. (2000), who compared different internal and external markers with the total collection of feces method and stated that the means obtained with iADF were the closest to the figure obtained by total collection, when the samples were incubated in vitro for six days. However, the incubation for three days did not provide satisfactory results, suggesting that iNDF was as efficient as iADF. Detmann et al. (2001), by contrast, reported that iDM and iNDF provided the best results and recommended their use for grazing animals. Zeoula et al. (2002) also noticed that the fecal recovery of iNDF did not differ from $100 \%$, unlike the fecal recovery of iADF. Detmann et al. (2007) attributed the low accuracy of ADF to its low content in the diet, orts, and feces, so more careful analytical procedures should be adopted to increase the precision of results.

\section{Conclusions}

Inclusion of pineapple pulp in silage at $758 \mathrm{~g} \mathrm{~kg}^{-1}$ has no influence on feed intake, while addition of urea only increases the intake of crude protein. The levels of pineapple pulp in silage with or without urea increase the digestibility of the silage.

Indigestible acid detergent fiber is the internal marker of least variability in recovery, because of the animal diets; its mean recovery for the four silages used is very close to $100 \%$. Chromium oxide, despite presenting mean recovery 
slightly above $100 \%$, has lower variability in estimates for treatments, individually. There are no differences between collection times and methods.

\section{Acknowledgments}

The fifth author is grateful for a post-doctoral fellowship provided by the Rio de Janeiro Research Foundation (Fundação Carlos Chagas Filho de Amparo à Pesquisa do Estado do Rio de Janeiro - FAPERJ), case no. E-26/101.429/2014, and the Brazilian Federal Agency for the Support and Evaluation of Graduate Education (Coordenação de Aperfeiçoamento de Pessoal de Nível Superior - CAPES), case no. E-45/2013-PAPDRJ.

\section{References}

AGRIANUAL - Anuário da agricultura brasileira. 2012. FNP, ed. Argos Comunicação, São Paulo, SP.

AOAC - Association of Official Analytical Chemistry. 1990. Official methods of analysis. 15th ed. AOAC International, Arlington, VA.

Azevêdo, J. A. G.; Valadares Filho, S. C.; Pina, D. S.; Detmann, E.; Valadares, R. F. D.; Pereira, L. G. R.; Souza, N. K. P. and Silva, L. F. C. 2011. Consumo, digestibilidade total, produção de proteína microbiana e balanço de nitrogênio em dietas com subprodutos de frutas para ruminantes. Revista Brasileira de Zootecnia 40:1052-1060.

Berchielli, T. T.; Andrade, P. and Furlan, C. L. 2000. Avaliação de indicadores internos em ensaios de digestibilidade. Revista Brasileira de Zootecnia 29:830-833.

Cochran, R. C.; Adams, D. C.; Wallace, J. D. and Galyean, M.L. 1986. Predicting digestibility of different diets with internal markers: evaluation of four potential markers. Journal of Animal Science 63:1476-1483.

Detmann, E.; Paulino, M. F.; Joanis, T. Z.; Valadares Filho, S. C.; Euclydes, R. F.; Lana, R. P. and Queiroz, D. S. 2001. Cromo e indicadores internos na determinação do consumo de novilhos mestiços, suplementados, a pasto. Revista Brasileira de Zootecnia 30:1600-1609.

Detmann, E.; Souza, A. L.; Garcia, R.; Valadares Filho, S. C.; Cabral, L. S. and Zervoudakis, J. T. 2007. Avaliação do vício de tempo longo de indicadores internos em ensaio de digestão com ruminantes. Arquivo Brasileiro de Medicina Veterinária e Zootecnia 59:182-188.

Fahey, G. C. and Jung Jr., H. G. 1983. Lignin as a marker in digestion studies: A review. Journal of Animal Science 57:220-225.

Ferreira, A. C. H.; Neiva, J. N. M.; Rodriguez, N. M.; Campos, W. E. and Borges, I. 2009. Avaliação nutricional do subproduto da agroindústria de abacaxi como aditivo de silagem de capimelefante. Revista Brasileira de Zootecnia 38:223-229.

Fontes, C. A. A.; Oliveira, M. A. T.; Lana, R. P.; Peron, A. J.; Valadares Filho, S. C. and Leão, M. I. 1996. Avaliação de indicadores na determinação da digestibilidade em novilhos. Revista da Sociedade Brasileira de Zootecnia 25:529-539.

Hennessy, D. W.; Kohun, P. J.; Williamson, P. J.; Brown, D. A. and Nolan, J. V. 1995. The effect of nitrogen and protein supplementation on feed intake, growth and digestive function of steers with different Bos indicus, Bos taurus genotypes when fed a low quality grass hay. Australian Journal of Agriculture Research 46:1121-1136.
Hopper, J. T.; Holloway, J. W. and Butts JR., W. T. 1978. Animal variation in chromium sesquioxide excretion patterns of grazing cows. Journal of Animal Science 46:1098-1102.

IBGE - Instituto Brasileiro de Geografia e Estatística. 2012. Dados de safra de abacaxi no Brasil. On-line. Available at: <ftp://ftp.ibge.gov.br>. Accessed on: Aug. 29, 2014.

Iturbide, A. C. 1967. El óxido crómico como indicador externo para estimar producción fecal y consumo en las pruebas de digestibilidad. Turrialba 7:304-313.

Kimura, F. T. and Miller, V. L. 1957. Chromium oxide measurement. Improved determination of chromium oxide in cow feed and feces. Journal of Agricultural and Food Chemistry 5:216-216.

Krysl, L. J.; Galyean, M. L.; Estell, R. E. and Sowell, B. F. 1988. Estimating digestibility and faecal output in lambs using internal and markers. Journal of Agricultural Science 111:19-25.

Köeppen, W. 1948. Climatologia. Ed. Panamericana, Buenos Aires, Argentina.

Lippke, H.; Ellis, W. C. and Jacobs, B. F. 1986. Recovery of indigestible fiber from feces of sheep and cattle on forage diets. Journal of Dairy Science 69:403-412.

Mertens, D. R. 1994. Regulation of forage intake. p.450-493. In: Forage quality, evaluation and utilization. Fahey, G. C., ed. American Society of Agronomy, Madison.

Minson, D. J. 1990. Forage in ruminant nutrition. Academic Press, New York.

Müller, Z. O. 1978. Feeding potential of pineapple waste for cattle. World Animal Review 25: 25-29.

Okamoto, J. H. H.; Andrade, P.; Andrade, A. T.; Sampaio, A. A. M. and Oliveira, M. S. 1988. Valor nutritivo de silagens feitas com resíduo industrial do milho verde e abacaxi para ovinos. Revista da Sociedade Brasileira de Zootecnia 17:147-152.

Owens, F. N. and Hanson, C. F. 1992. External and internal markers for appraising site and extent of digestion in ruminants. Journal of Animal Science 75:2605-2617.

Penning, P. D. and Johnson, R. H. 1983. The use of internal markers to estimate herbage digestibility and intake. 2. Indigestible acid detergent fiber. Journal of Agriculture Science 100:133-138.

Piaggio, L. M.; Prates, E. R.; Pires, F. F. and Ospina, H. 1991. Avaliação das cinzas insolúveis em ácido, fibra em detergente ácido indigestível e lignina em detergente ácido indigestível como indicadores internos da digestibilidade. Revista da Sociedade Brasileira de Zootecnia 20:306-312.

Sampaio, C. B.; Detmann, E.; Valente, T. N. P.; Souza, M. A.; Valadares Filho, S. C. and Paulino, M. F. 2011. Evaluation of fecal recovering and long term bias of internal and external markers in a digestion assay with cattle. Revista Brasileira de Zootecnia 40:174-182.

Schaadt, H., Johnson, R. R. and McClure, K. E. 1966. Adaptation to and palatability of urea, biuret and diammonium phosphate as NPN sources for ruminants. Journal of Animal Science 25:73-77.

Resende, K. T.; Furlan, C. L.; Costa, R. G.; Sugohara, A.; Vasconcelos, V. R.; Carvalho, F. F. R. and Guideli, C. 1996. Utilização do colágeno cromatado como indicador em estudos de digestão com caprinos. Revista da Sociedade Brasileira de Zootecnia 25:806-813.

Van Soest, P. J.; Robertson, J. B. and Lewis, B. A. 1991. Methods for dietary fiber, neutral detergent fiber, and nonstarch polysaccharide in relation to animal nutrition. Journal of Dairy Science 74:3583-3597.

Van Soest, P. J. 1994. Nutritional ecology of the ruminant. 2nd ed. Cornell University Press, New York.

Zeoula, L. M.; Prado, I. N.; Dian, P. H. M.; Geron, L. J. V.; Caldas Neto, S. F.; Maeda, E. M.; Peron, P. D. P.; Marques, J. A. and Falcão, A. J. S. 2002. Recuperação fecal dos indicadores internos avaliados em ruminantes. Revista Brasileira de Zootecnia 31:1865-1874. 